preference to Bennettites, although in many respects the Portland stem is identical with Bennettites Gibsonianus. Externally, the surface is covered with rhomboidal areas separated from one another by a projecting framework consisting of the silicified ramental tissue, which thickly clothed the bases of the petioles. The peripheral portion of the stem afforded thin sections from which it was possible to investigate the anatomical structure of the leaf-bases and ramental scales. Internally, the wood-and pith-tissues have been entirely replaced by inorganic material. The author calls attention to the preservation of a prominent apical bud covered with narrow bud-scales and capped by a mass of ramenta. No indication is found of a lateral inflorescence such as characterizes Bennettites Gibsonianus, and the negative evidence suggests the occurrence of terminal reproductive structures. A comparison of this fossil with recent Cycads and Ferns brings ont many points of close agreement with the former; and as regards the structure of the ramenta, evidence is afforded of an interesting survival of the closer resemblance which formerly existed between Cycadean and Fern-like plants. The stem is named Cycadeoidea gigantea.

2. "The Famna of the Keisley Limestone.-Part II. Conclusion." By F. R. C. Reed, Esq., M.A., F.G.S.

The author describes the Ostracoda, Brachiopoda, Mollusca, Echinodermata, and Actinozoa of the Keisley Limestone. He gives a list of fossils from the Limestone, and indicates those species which occur in the Limestone of Kildare, the Leptana-Limestone of Sweden, and Stacre F, of the East Baltic provinces. As a result of his researches he concludes that the fauna has a thoroughly Ordovician facies; that it is closely comparable with that of the Limestone of the Chair of Kildare, and of the Leptena-Limestone, and less closely with that of Stagre F, of the East Baltic provinces; that its palæontological features point to its stratigraphical position being at the base of the Upper Bala, and that it must be regarded as the locally thickened development of a bed which is elsewhere in Great Britain very thin, or entirely absent, or represented by beds having different lithological characters and a different fauna; and that the fanna has certain unique characters which mark it off from all other known assemblages of fossils in Great Britain.

\title{
COREESPONDENOEF.
}

\section{LIFE-ZONES IN THE BRITISH CARBONIFEROUS ROCKS.}

Sir,-In the November Number of the Geological Magazine, the Report of the Committee appointed by the British Association to study the Life-zones of the British Carboniferous rocks, contains a list of the Committee, from which the name of Dr. R. H. Traquair, who has kindly undertaken to report on Carboniferous fish, is omitted. As onr Report is likely to become known to workers largely through the inedium of the Magazine, I should be greatly obliged if you would kindly insert this correction.

Cambridae, December 5, 1896.

JoHn E. MarR. 